\title{
TRADISI SATU BULAN BAYI PADA PASANGAN \\ CAMPURAN ETNIS TIONGHOA DAN ETNIS JAWA DI SURABAYA \\ 探讨驻泗水的印尼华族与爪哇族通婚对婴儿满月 \\ 仪式活动
}

\author{
Elizabet Sanjaya \\ Olivia S.E., M.A. \& Hannie Kwartanti,S.S.M.Sosio. \\ Program Studi Sastra Tionghoa Universitas Kristen Petra, \\ Siwalankerto 121-131, Surabaya 60236 \\ E-mail: elizabetsan96@gmail.com, olivia@petra.ac.id,hanniekpa@gmail.com
}

\begin{abstract}
ABSTRAK
Indonesia memiliki berbagai macam kebudayaan dan etnis di dalamnya. Setiap etnis yang ada juga memiliki beberapa tradisi yang dilakukan untuk memperingati atau merayakan hari-hari tertentu, salah satunya yaitu tradisi dalam merayakan satu bulan bayi. Tujuan dari penelitian ini untuk mengetahui tradisi apa yang dilakukan oleh pasangan campuran etnis Tionghoa dan etnis Jawa dalam merayakan satu bulan bayi. Diharapakan dari penelitian ini dapat mengetahui, memahami dan memberikan inspirasi kepada pasangan orang tua yang lain. Penelitian ini dilakukan menggunakan metode kualitatif deskriptif, dengan cara melakukan wawancara kepada sepuluh pasangan orang tua campuran etnis Tionghoa dan etnis Jawa. Hasil dari penelitian menunjukkan bahwa pasangan campuran tersebut tidak semuanya melakukan tradisi yang ada. Tradisi yang masih dilakukan yaitu memotong rambut bayi. Selain itu hantaran yang diberikan untuk keluarga dan kerabat juga berbagai macam.
\end{abstract}

Kata kunci: tradisi, manyue, selametan selapanan.

\section{摘要}

印度尼西亚是一个多元文化和民族的国家。每个族也有一些纪念或庆 祝节日的传统仪式, 其中之一是庆祝一个婴儿满一个月的传统仪式。这篇论 文的研究动机是想知道通婚的印尼华族与爪哇族如何举办满月。这篇论文的 研究目是想要更了解印尼华族与爪哇族通婚会采用什么方式来庆祝满月。这 项研究采用描述性的定性方法进行, 通过采访十个双亲印尼华族和爪哇族。 从研究的结果我们可以看出的是个双亲并不是每个人会选择用他们种族的传 统仪式。使用传统的是剃头的活动。此外，许多父母选择送各种各样的满月 礼品给他们的亲友。

关键词: 传统、满月、selametan selapanan. 


\section{PENDAHULUAN}

Indonesia merupakan negara yang memiliki keanekaragaman budaya yang tinggi. Keanekaragaman budaya tersebut tidak hanya berasal dari kebudayaan suatu daerah saja, tetapi juga dipengaruhi oleh kebudayaan asing yang masuk ke suatu daerah tersebut. Sosialisasi antar budaya ini tak jarang sampai ke tahap pernikahan.

Keragaman budaya dalam kehidupan pernikahan ini banyak kita jumpai dalam kehidupan sehari-hari. Sebagai salah satu contoh adalah kota Surabaya. Memiliki dua kebudayaan yang paling dominan yaitu kebudayaan etnis Tionghoa dan etnis Jawa. Masing-masing etnis tersebut memiliki tradisi tersendiri dalam merayakan hari-hari penting, contohnya dalam rangka kelahiran bayi, satu bulanan bayi, dan masih banyak lagi. Kelahiran dianggap sebagai suatu peristiwa yang penting dan berharga dalam kehidupan manusia karena kelahiran merupakan awal kehidupan seseorang yang muncul kedunia ini. Oleh karena itu, sebagai rasa syukur atas satu bulan kelahiran bayi tersebut, maka diberikannya beberapa hantaran yang mempunyai makna tersendiri kepada sanak keluarga dan kerabat.

Tradisi satu bulan bayi yang dilakukan dalam etnis Tionghoa disebut dengan manyue. "Man" artinya penuh, berisi dan "Yue" artinya bulan (Kamus Besar Tionghoa-Indonesia 2010:204). Tradisi manyue ini biasanya sering dirayakan dengan cara memberikan telur merah kepada keluarga atau relasi. Telur merah merupakan telur yang diberi pewarna merah tua. Jumlah telur yang digunakan tergantung dari jenis kelamin anak tersebut, yaitu anak perempuan atau anak lakilaki. Banyak orang yang memberikan telur merah ketika satu bulan bayi karena dipercayai sebagai tanda kebahagiaan dan permulaan hidup yang baru. Selain memberikan telur merah, beberapa orang juga memberikan kue. Kue yang digunakan sebagian besar seperti cake atau tart yang melambangkan panjang umur dan adanya rejeki dalam keluarga.

Sedangkan tradisi satu bulan bayi dalam etnis Jawa disebut dengan Selametan Selapanan. Tradisi ini dilakukan ketika bayi berumur 35 hari. Dalam etnis Jawa, mereka mempunyai perhitungan dalam kalender Jawa. Oleh sebab itu mengapa dirayakannya ketika 35 hari setelah bayi tersebut lahir. Perhitungan tersebut dikarenakan hari lahir anak tersebut akan jatuh di hari yang sama ketika anak tersebut merayakan ulang tahun. Di hari itu juga beberapa orang tua akan melakukan beberapa tradisi dan tidak lupa untuk memberikan hantaran kepada keluarga dan relasi dengan berbagai macam jenis, salah satu yang digunakan yaitu tumpeng gudangan, atau jajanan pasar.

Seperti dijelaskan diatas bahwa memberikan beberapa hantaran sebagai rasa syukur orang tua atas kelahiran bayi tersebut. Akan tetapi dalam pelaksanaannya, beberapa pasangan orang tua campuran yang berasal dari etnis Tionghoa dan etnis Jawa memberikan hantaran tersebut dengan isi yang bermacam-macam, dan merupakan gabungan antara yang dilakukan kedua etnis tersebut. Beberapa penelitian sebelumnya yang membahas mengenai manyue, mereka hanya membahas mengenai upacara-upacara yang dilakukan selama manyue. Upacara yang pada umumnya dilakukan oleh kedua etnis tersebut. Hal ini mendorong penulis untuk mengetahui apa saja tradisi, serta jenis hantaran yang digunakan 
dalam merayakan satu bulanan bayi yang dilakukan oleh pasangan orang tua campuran etnis Tionghoa dan etnis Jawa.

Maka terdapat dua rumusan masalah pada penelitian ini yaitu yang pertama, bagaimana tradisi satu bulan bayi yang digunakan oleh pasangan orang tua etnis Tionghoa dan etnis Jawa? Kedua, faktor-faktor apa saja yang digunakan dalam memilih tradisi satu bulan bayi oleh pasangan campuran etnis Tionghoa dan etnis Jawa?

\section{KAJIAN PUSTAKA}

\section{Ritus}

Ritus dan upacara adalah komponen penting dalam sistem religi. Ritus dan upacara dalam sistem religi berwujud aktivitas dan tindakan manusia untuk berkomunikasi dan melaksanakan kebaktiannya terhadap Tuhan, dewa-dewa, roh nenek moyang, atau makhluk gaib lainnya. Ritus atau upacara religi biasanya berlangsung secara berulang-ulang, baik setiap hari, setiap musim atau kadangkadang saja. Tergantung dari acaranya, suatu ritus atau upacara religi biasanya terdiri dari suatu kombinasi yang merangkaikan satu, dua atau beberapa tindakan, yaitu: berdoa, bersujud, bersaji, berkorban, makan bersama, berpuasa, bertapa, dan bersemedi (Koentjaningrat 1987:81).

Dari beberapa kegiatan yang dilakukan tersebut, maka ritual juga mempunyai tujuan. Tujuan dari ritual ini seperti yang diungkapkan oleh Bustanuddin Agus (2007:95) yaitu untuk mendapatkan berkah atau rezeki yang banyak dari suatu pekerjaan. Seperti upacara menolak bala dan upacara karena perubahan atau siklus dalam kehidupan manusia seperti kelahiran, pernikahan dan kematian.

Ritus digolongkan ke dalam dua bagian menurut Winangun (1990:11) yaitu ritus krisis hidup dan ritus gangguan. Pertama, ritus krisis hidup yaitu ritus-ritus yang diadakan untuk mengiringi krisis-krisis hidup yang dialami manusia. Mengalami krisis, karena ia beralih dari satu tahap ke tahap berikutnya. Ritus ini meliputi kelahiran, pubertas, perkawinan dan kematian. Ritus-ritus ini tidak hanya berpusat pada individu, melainkan juga tanda adanya perubahan dalam relasi sosial diantara orang yang berhubungan dengan mereka, dengan ikatan darah, perkawinan, kontrol sosial dan sebagainya. Kedua, ritus gangguan. Pada ritus gangguan ini masyarakat menghubungkan nasib sial dalam berburu, ketidak teraturan reproduksi pada para wanita dan lain sebagainya dengan tindakan roh orang yang mati. Roh leluhur mengganggu orang sehingga membawa nasib sial.

\section{Makna}

Dalam kamus besar bahasa Tionghoa (2018), makna memiliki dua arti yaitu:

1. Makna merupakan pemahaman seseorang terhadap alam sekitar atau halhal sosial, yaitu makna yang diberikan oleh orang terhadap benda-benda, yaitu konten spiritual yang ditransmisikan dan dikomunikasikan manusia dalam bentuk 
simbolik. Orang dalam menyebarluaskan kegiatan komunikasi dari isi konten spiritual, termasuk maksud, makna, keniatan, pengetahuan, pengetahuan, nilai, konsep, dan lain sebagainya. Semua termasuk dalam kategori ruang lingkup makna.

2. Makna yang ditampilkan oleh kata-kata atau simbol lainnya, isi dan kebenaran dari suatu benda.

\section{Interaksi Sosial}

Menurut Emillia (2014:71) dalam setiap interaksi yang terjadi antara orang perorangan akan didahului dengan adanya kontak sosial dan komunikasi. Pasangan Jawa Tionghoa yang dimana pihak wanitanya adalah etnis Jawa, dalam kehidupan berkeluarga mereka akan terlihat bahwa kedudukan suami sangat dipandang tinggi. Sedangkan dalam pasangan Jawa Tionghoa yang dimana pihak wanitanya beretnis Tionghoa akan lebih berpandangan bahwa meskipun posisi suami adalah kepala keluarga namun bukan berarti istri harus tunduk pada suami.

Menurut H.Booner dalam bukunya Social Psychology, memberikan rumusan interaksi sosial, bahwa: "Interaksi sosial adalah hubungan antara dua individu atau lebih, di mana kelakuan individu yang satu mempengaruhi, mengubah, atau memperbaiki kelakukan individu yang lain atau sebaliknya." (Setiadi et al, 2006, p. 90-91).

\section{Tradisi Satu Bulan Bayi Etnis Tionghoa}

Satu bulan bayi dalam etnis Tionghoa biasanya disebut dengan manyue. Menurut Kamus Besar Tionghoa-Indonesia (2010:204) tradisi manyue merupakan salah satu tradisi yang berasal dari Tiongkok dan dilakukan ketika usia bayi mencapai satu bulan atau tepatnya 30 hari saat bayi dilahirkan.

Tradisi dalam satu bulan bayi etnis Tionghoa menurut Yeo (2013) yaitu:

1. Ketika bayi memasuki 30 hari, ibu diizinkan untuk mandi pertama dan mencuci rambutnya. Selain itu pada hari yang sama juga dilakukan ritual pencukuran rambut bayi.

2. Di beberapa keluarga, bayi akan mengenakan pakaian baru, lebih disukai merah, serta dihiasi aksesoris emas untuk disajikan kepada leluhur dan dewa di rumah. Ini untuk menginformasikan nenek moyang adanya tambahan baru ke rumah tangga dan untuk memohon roh-roh untuk melindungi bayi yang baru lahir.

Tradisi menurut Siagian (2015:15) yang dilakukan pada saat satu bulan bayi etnis Tionghoa yaitu:

1. Upacara adat kelahiran atau manyue sering disebut juga dengan upacara pemberian telur merah. Telur yang melambangkan suatu tahapan kehidupan yang baru, sedangkan warna merah melambangkan perayaan dan keberuntungan. Bentuk telur yang oval melambangkan harmoni dan kesatuan. Jadi telur merah menandakan kebahagiaan dan permulaan hidup yang baru dengan hadirnya seorang bayi ditengah-tengah keluarga.

2. Mencukur rambut sang bayi harus dilakukan dengan hati-hati dan waspada. Di beberapa daerah rambut sang bayi yang sudah dicukur atau biasa juga dengan 
cara rambut sang bayi dibentuk bulat-bulat dengan menggunakan tangan lalu digulung dengan benang sutra atau kain merah dan dijahit pada bantalnya. Dengan begini, diharapkan bayi menjadi lebih baik, tidak akan gugup atau mudah takut.

3. Kakek dan nenek dari keluarga dalam dan keluarga luar memberikan hadiah berupa gelang, kalung emas kepada bayi perempuan. Pemberian emas ini bermakna sebagai doa akan keberuntungan sang bayi kelak seperti emas dan pada bayi lakilaki diberikan angpao. Angpao juga dimaknai sebagai doa keberuntungan agar sang bayi laki-laki kelak mendapat keberuntungan selama hidupnya.

Menurut Siagian (2015:65) beberapa macam hantaran yang diberikan yaitu: telur merah, pisang dua buah yang bergandengan, macam-macam kue (kue tart, kue apem, kue kura-kura), 1 ekor ayam, mie.

\section{Tradisi Satu Bulan Bayi Etnis Jawa}

Tradisi satu bulan bayi dalam etnis Jawa diperingati ketika bayi tersebut sudah berusia 35 hari, Selametan Selapanan. Menurut Ulumiyah (2010:14) pada penanggalan Jawa yang berjumlah 5 (wage, pahing, pon, kliwon, legi) akan bertemu pada hari 35 dengan hari di penanggalan masehi yang berjumlah 7. Dalam hitungan tersebut, 35 hari dapat diketahui dari kelipatan 5 dan 7. Pada saat selapan weton bayi akan berulang, bisa dikatakan hari ulang tahun dalam versi penanggalan Jawa. Terlepas dari itu semua, tradisi selametan selapanan merupakan wujud rasa syukur kepada Allah SWT yang telah mengkaruniai anak, dan harapan orang tua agar anaknya dapat menjadi akan yang sholih sholihah.

Tradisi yang dilakukan ketika selametan selapanan biasanya rambut bayi akan dipotong dan hasil potongannya akan dijadikan satu dengan tali pusar. Tujuan dari memotong rambut yaitu untuk membersihkan rambut yang masih terkena air ketuban dan menjaga kulit kepala tetap bersih (Ulumiyah 2010:14).

Menurut Aswiyati (2015:6) disediakan beberapa macam hantaran yang memiliki makna tersendiri, contohnya: Sekul tumpeng gudangan, jenang abang, jenang putih, jenang baro-baro, jajanan pasar, sekul gelong, sekul asrap-asrapan, pecel ayam, tumpeng inthuk-inthuk, jangan menir, telur ayam, nasi kuning.

\section{METODE PENELITIAN}

Penelitian ini merupakan penelitian kualitatif. Metode pendekatan yang digunakan adalah pendekatan kualitatif deskriptif, karena menguraikan hasil observasi penelitian dengan menggunakan kata-kata, bukan dengan angka. Sumber data dalam penelitian ini adalah 10 pasang orang tua etnis Tionghoa dan etnis Jawa. Kriteria dari sumber data tersebut adalah 5 pasang orang tua yaitu pihak laki-laki etnis Jawa dan pihak perempuan etnis Tionghoa. 5 pasang orang tua yaitu pihak laki-laki etnis Tionghoa dan pihak perempuan etnis Jawa. Teknik pengumpulan data yang digunakan adalah wawancara semi-terstuktur. Penulis akan mencari pasangan yang telah menikah campur dan sudah merayakan 1 bulanan bayi (manyue/selametan selapanan). Pertama kali penulis akan memperkenalkan dirinya terlebih dahulu sebelum melakukan wawancara, setelah itu penulis akan menanyakan kesediaan narasumber untuk diwawancara. Setelah semuanya 
bersedia, penulis menanyakan beberapa data narasumber seperti nama, profesi, alamat, umur, agama. Wawancara semi-terstuktur memiliki pengertian bahwa pertanyaan telah dipersiapkan terlebih dahulu, kurang lebih terdapat 15 pertanyaan wawancara yang akan diajukan kepada narasumber.

\section{ANALISIS}

\section{Pasangan pihak laki-laki etnis Jawa dan pihak perempuan etnis Tionghoa}

Berikut data setiap pasangan orang tua campuran yang telah merayakan satu bulan bayi yang diperoleh dari hasil wawancara:

a. Pasangan pertama, pihak laki-laki etnis Jawa dan pihak perempuan etnis Tionghoa. Pasangan tersebut menganut agama Kristen, dan bekerja sebagai wirausaha. Mereka dikaruniai satu orang anak laki-laki berusia 4 tahun. Pasangan tersebut dahulu tinggal di Surabaya lalu pindah ke luar kota. Mereka memiliki status sosial menengah keatas. Pasangan tersebut memilih merayakan satu bulan bayi dengan cara tidak melakukan tradisi apapun. Mereka juga tidak mengetahui tradisi asli yang dijalankan ketika merayakan satu bulan bayi. Pasangan tersebut tetap memberikan hantaran berupa 1 kotak berisi 1 ekor ayam kepada keluarga dan relasi. Akan tetapi pasangan ini tidak mengetahui makna dari hantaran yang digunakan. Semua keputusan yang diambil untuk merayakan satu bulan bayi anaknya hanya berdasarkan hasil diskusi dengan suami.

b. Pasangan kedua, pihak laki-laki etnis Jawa dan pihak perempuan etnis Tionghoa. Pasangan tersebut menganut agama Kristen, dan bekerja sebagai wirausaha. Mereka dikaruniai satu orang anak perempuan berusia 3 tahun. Pasangan tersebut tinggal di lingkungan perumahan yang cukup bagus, dan memiliki status sosial menengah keatas. Pasangan tersebut tidak mengetahui tradisi asli yang harus dilakukan, tetapi mereka memilih merayakan satu bulan bayi dengan cara memotong rambut bayi hingga gundul. Mereka melakukan tradisi tersebut dengan harapan agar bayi tersebut menjadi lebih baik, karena rambut yang berasal dari dalam kandungan ibu masih belum terlalu bersih. Pasangan ini juga memberikan hantaran berupa cake yang diberikan kepada keluarga dan relasi, tetapi mereka kurang mengerti makna dari jenis hantaran yang mereka gunakan. Pasangan ini saling berdiskusi untuk menentukan tradisi dan hantaran apa yang akan digunakan.

c. Pasangan ketiga, pihak laki-laki etnis Jawa dan pihak perempuan etnis Tionghoa. Pasangan tersebut menganut agama Kristen, dan bekerja sebagai wirausaha. Mereka dikaruniai satu orang anak laki-laki berusia 1.5 tahun. Pasangan tersebut dahulu tinggal di Surabaya lalu sekarang pindah ke luar kota. Mereka memiliki status sosial menengah keatas. Pasangan ini tidak mengetahui tradisi asli apa saja yang dilakukan ketika satu bulan bayi. Mereka lalu mengikuti apa yang dilakukan kebanyakan orang yaitu merayakan satu bulan bayi dengan cara memotong rambut bayi hingga gundul. Mereka mempercayai jika memotong rambut bayi hingga gundul agar bayi tersebut lebih bersih, seperti dilahirkan kembali. Selain melakukan tradisi potong rambut, mereka memberikan hantaran tersebut mengikuti perkembangan zaman yaitu berupa souvenir berisi gelas, handuk, dan 1 toples isi makanan ringan. Hantaran tersebut juga diberikan kepada keluarga 
dan relasi. Semua keputusan juga merupakan hasil diskusi dalam memilih merayakan satu bulan bayi. Di hari itu, bayi juga memakai baju berwarna merah. Orang tua dari bayi tersebut merayakan dengan keluarga terdekat saja di rumah dan memesan tumpeng dan cake, sebagai simbol dan dimakan oleh keluarga sendiri. Kakek nenek dari bayi itu juga memberikan angpao kepada bayi tersebut sebagai syarat.

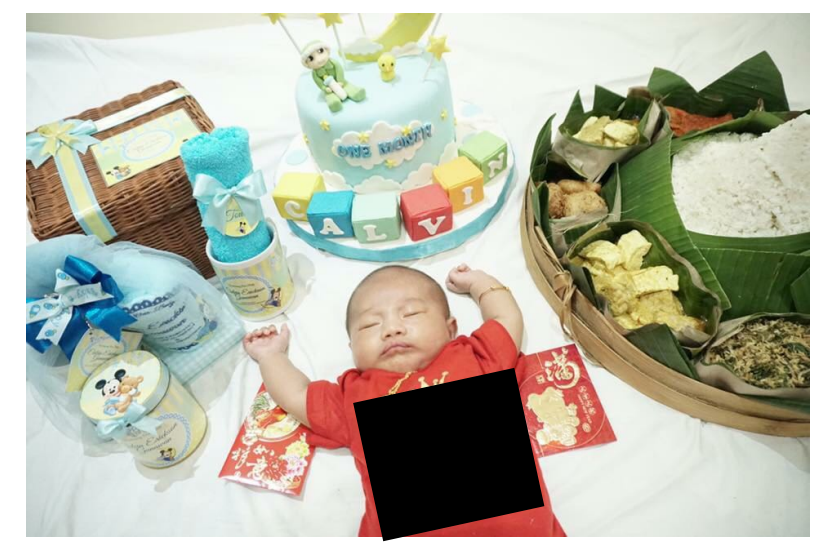

Gambar 4.1 tradisi dan hantaran yang digunakan ketika merayakan satu bulan bayi oleh pasangan ketiga.

d. Pasangan keempat, pihak laki-laki etnis Jawa dan pihak perempuan etnis Tionghoa. Pasangan tersebut menganut agama Kristen. Memiliki pekerjaan sebagai wirausaha. Mereka dikaruniai satu anak laki-laki yang kini berusia 7 tahun. Pasangan tersebut tinggal di lingkungan perumahan yang cukup bagus, dan memiliki status sosial menengah keatas. Pasangan ini tidak mengetahui tradisi apa saja dan mereka memilih merayakan 1 bulan bayi dengan cara tidak melakukan tradisi apapun. Mereka memutuskan memberikan hantaran kepada keluarga dan relasi berupa nasi urap sebagai ungkapan terima kasih kepada orang yang sudah datang untuk melihat bayinya. Tetapi mereka tidak mengerti makna dari jenis hantaran tersebut. Tidak ada faktor-faktor khusus dalam memutuskan merayakan satu bulan bayi. Semua hasil diskusi antara pihak keluarga.

e. Pasangan kelima, pihak laki-laki etnis Jawa dan pihak perempuan etnis Tionghoa. Pasangan tersebut menganut agama Kristen, dan bekerja sebagai pegawai. Mereka dikaruniai satu orang anak perempuan berusia 3 tahun. Pasangan tersebut tinggal di lingkungan perumahan yang cukup bagus, dan memiliki status sosial menengah keatas. Pasangan tersebut tidak mengetahui tradisi apa saja yang dijalankan dalam tradisi etnis Jawa. Mereka memilih merayakan satu bulan bayi dengan cara tidak melakukan tradisi apapun, tetapi memberikan hantaran kepada keluarga dan relasi berupa 1 kotak berisi nasi kuning. Keputusan yang dipilih dalam memilih jenis hantaran tersebut karena bisa dimakan oleh orang. Akan tetapi semua keputusan tetap berdasarkan keputusan hasil diskusi antara kedua belah pihak. 


\section{Pasangan pihak laki-laki etnis Tionghoa dan pihak perempuan etnis Jawa}

Berikut data setiap pasangan orang tua campuran yang telah merayakan satu bulan bayi yang diperoleh dari hasil wawancara:

a. Pasangan keenam, pihak laki-laki etnis Tionghoa dan pihak perempuan etnis Jawa. Pasangan tersebut menganut agama Kristen, dan bekerja sebagai wirausaha. Mereka dikaruniai satu orang anak laki-laki berusia 9 tahun. Pasangan tersebut tinggal di lingkungan perumahan yang cukup bagus. Mereka memiliki status sosial menengah keatas. Pasangan tersebut tidak mengetahui tradisi asli yang dilakukan dalam merayakan satu bulan bayi. Mereka memilih merayakan satu bulan bayi dengan cara memotong rambut bayi hingga gundul. Mereka hanya mengikuti tradisi tersebut tanpa mengetahui makna dari tradisi yang mereka jalani. Selain memotong rambut, pasangan ini juga memberikan hantaran kepada keluarga dan relasi berupa 1 kotak berisi 1 ekor ayam dan kue spiku. Alasan menggunakan jenis hantaran tersebut karena bisa dimakan oleh orang dan lebih praktis. Semua keputusan dipilih oleh pihak perempuan karena pihak laki-laki hanya mengikuti saja.

b. Pasangan ketujuh merupakan pihak laki-laki etnis Tionghoa dan pihak perempuan etnis Jawa. Pasangan tersebut menganut agama Kristen, dan bekerja sebagai wirausaha. Mereka dikaruniai satu orang anak laki-laki berusia 2 tahun. Pasangan tersebut tinggal di lingkungan perumahan yang cukup bagus. Mereka memiliki status sosial menengah keatas. Pasangan tersebut juga tidak mengetahui tradisi apa yang biasanya dilakukan ketika satu bulan bayi. Tetapi ia tetap memilih merayakan satu bulan bayi seperti apa yang dilakukan pada umumnya yaitu dengan cara memotong rambut bayi hingga gundul. Mereka melakukan tradisi tersebut agar bayi menjadi lebih bersih. Pasangan tersebut juga memberikan hantaran kepada keluarga dan relasi berupa kue roll tart dan telur merah. Mereka memilih menggunakan hantaran tersebut agar lebih praktis dan bisa dimakan orang. Tidak ada faktor khusus dalam menentukan tradisi dan hantaran yang digunakan oleh pasangan tersebut.

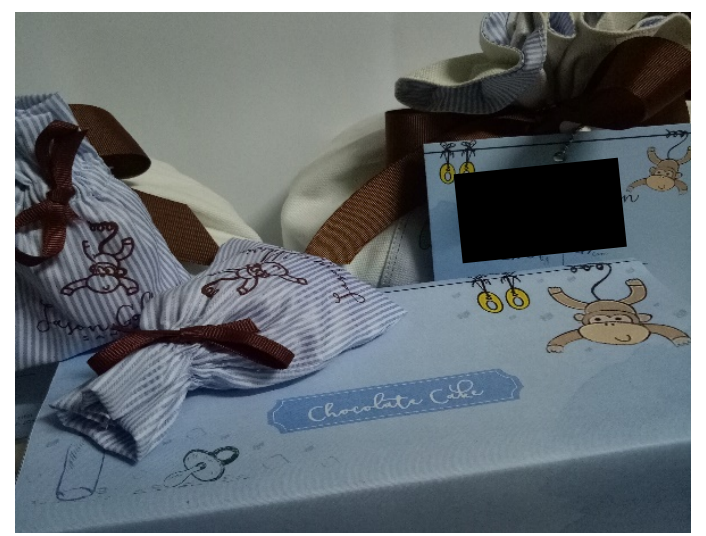

Gambar 4.2 hantaran yang digunakan ketika merayakan satu bulan bayi oleh pasangan ketujuh.

c. Pasangan kedelapan, pihak laki-laki etnis Tionghoa dan pihak perempuan etnis Jawa. Pasangan tersebut menganut agama Kristen, dan bekerja sebagai pegawai. Mereka dikaruniai satu orang anak perempuan berusia 3 tahun. Pasangan tersebut tinggal di lingkungan perumahan yang cukup bagus. Mereka memiliki 
status sosial menengah keatas. Pasangan tersebut memilih merayakan satu bulan bayi dengan cara tidak melakukan kedua tradisi. Akan tetapi mereka tetap memberikan hantaran kepada keluarga dan relasi berupa gelas dan makanan ringan. Mereka juga memilih jenis hantaran tersebut karena mengikuti perkembangan zaman. Dalam menentukan merayakan satu bulan bayi tersebut merupakan hasil dari keputusan bersama kedua belah pihak.

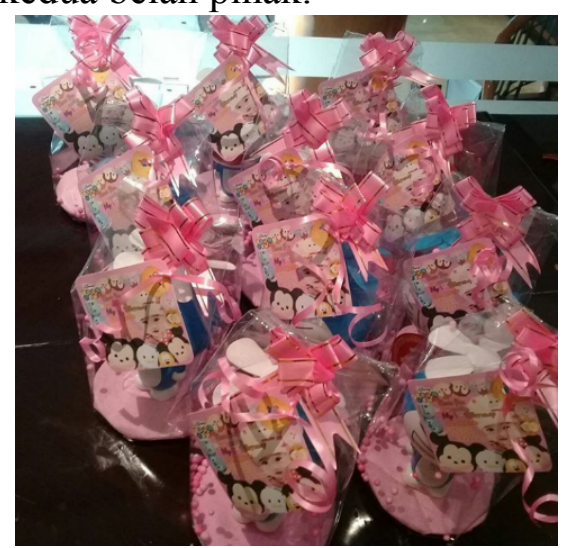

Gambar 4.3 hantaran yang digunakan dalam merayakan satu bulan bayi oleh pasangan kedelapan

d. Pasangan kesembilan, pihak laki-laki etnis Tionghoa dan pihak perempuan etnis Jawa. Pasangan tersebut menganut agama Kristen, dan bekerja sebagai wirausaha. Mereka dikaruniai dua orang anak, yang satu anak laki-laki berusia 3 tahun, anak kedua perempuan berusia 1 tahun. Pasangan tersebut tinggal di lingkungan perumahan yang cukup bagus. Mereka memiliki status sosial menengah ke atas. Pasangan tersebut memilih merayakan satu bulan bayi dengan cara tidak melakukan tradisi apapun, baik tradisi etnis Tionghoa atau etnis Jawa. Mereka memilih memberikan hantaran kepada keluarga dan relasi berupa 1 kotak yang berisi gelas dan handuk dan untuk anak kedua berupa 1 tas berisi gelas dan kue kering. Mereka memilih jenis hantaran tersebut karena mengikuti perkembangan zaman yang lebih praktis. Keputusan yang diambil berdasarkan hasil diskusi dengan keluarga.
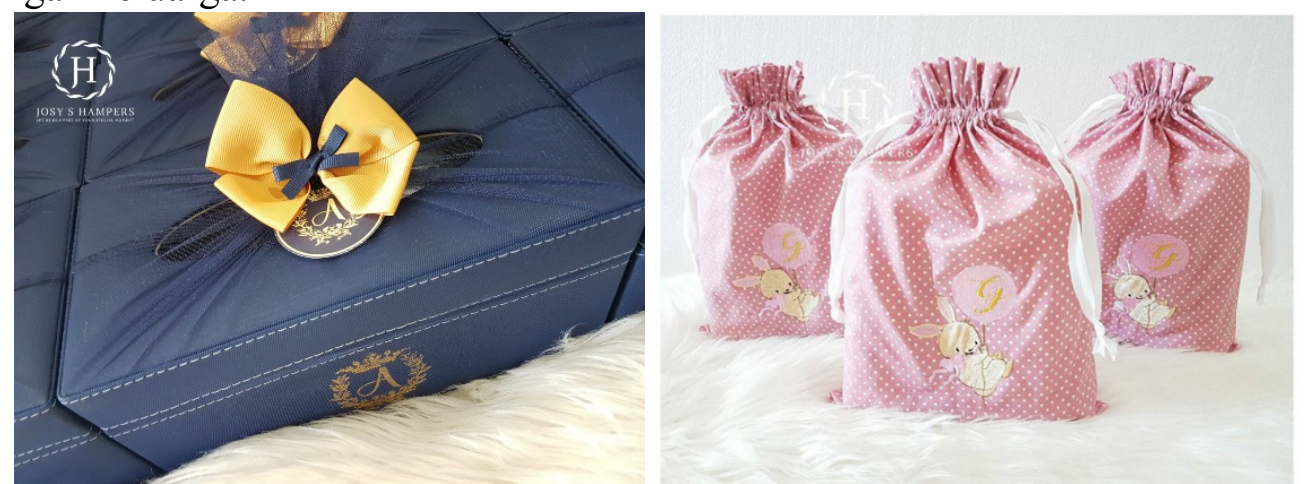

Gambar 4.4 dan gambar 4.5 hantaran yang digunakan dalam merayakan satu bulan bayi oleh pasangan kesembilan.

e. Pasangan kesepuluh, pihak laki-laki etnis Tionghoa dan pihak perempuan etnis Jawa. Pasangan tersebut menganut agama Kristen, dan bekerja sebagai wirausaha. Mereka dikaruniai satu orang anak perempuan berusia 8 tahun. Pasangan tersebut tinggal di lingkungan perumahan yang cukup bagus. Mereka 
memiliki status sosial menengah keatas. Pasangan ini juga tidak mengetahui tradisi apa saja yang dilakukan ketika merayakan satu bulan bayi. Mereka lalu memilih tidak merayakan tradisi satu bulan bayi. Mereka memutuskan untuk memberikan hantaran kepada keluarga dan relasi berupa 1 kotak berisi 1 ekor ayam. Pasangan tersebut memilih jenis hantaran makanan tersebut agar dapat dimakan oleh orang. Keputusan ini berdasarkan hasil diskusi antara pihak laki-laki dan pihak perempuan.

\section{Analisis pembahasan}

Tradisi yang digunakan oleh orang tua dimana pihak laki-laki etnis Jawa, pihak perempuan etnis Tionghoa, yaitu memilih merayakan satu bulan bayi pada hari ke-30. Pada hari itu mereka akan memotong rambut bayi hinggal gundul. Memotong rambut bayi pertama kali dilakukan oleh ayahnya, setelah itu akan dilanjutkan oleh orang dari salon sampai rambut bayi tersebut gundul. Mereka mempercayai jika memotong rambut bayi agar bayi tersebut lebih bersih seperti dilahirkan kembali. Selain itu ada tradisi lain yang dilakukan yaitu memberikan hantaran kepada keluarga dan kerabat dekat. Tujuan dari memberikan hantaran adalah sebagai ucapan terima kasih terutama kepada mereka yang telah datang untuk melihat bayi tersebut. Hantaran yang diberikan pun juga beraneka ragam, misalnya seekor ayam utuh, cake, gelas, handuk, kue ringan, nasi uduk, dan nasi kuning. Dalam memilih jenis hantaran tersebut, semua berdasarkan keputusan suami istri.

Dapat kita lihat dari hasil diatas, pada pasangan orang tua dimana pihak laki-laki merupakan etnis Jawa, dapat diketahui bahwa tradisi satu bulan bayi yang mereka gunakan sebagian besar tidak mengikuti pihak laki-laki sebagai kepala keluarga. Menurut Handoko (2014:71) pihak perempuan sebagai etnis Tionghoa akan berpandangan bahwa meskipun pihak laki-laki adalah kepala keluarga tetapi bukan berarti istri harus tunduk kepada suami. Melainkan pihak perempuan juga berperanan penting dalam memutuskan sesuatu.

Selain itu pasangan orang tua pihak laki-laki etnis Tionghoa, pihak perempuan etnis Jawa juga menggunakan tradisi yang pada umumnya dilakukan oleh etnis Tionghoa yaitu tradisi memotong rambut bayi hinggal gundul. Mereka juga merayakan satu bulan bayi pada hari ke-30. Pertama kali, ayah dari bayi tersebut akan memotong sedikit rambutnya lalu akan dilanjutkan oleh orang yang telah dipanggil untuk melanjutkan memotong rambut bayi hinggal gundul. Tujuan dari memotong rambut bayi hingga gundul, karena rambut yang berasal dari dalam kandungan ibu masih belum terlalu bersih. Hal lainnya yaitu agar bayi tersebut lebih bersih seperti dilahirkan kembali. Mereka juga memberikan hantaran kepada keluarga dan kerabat sebagai ucapan syukur kepada Tuhan karena sudah dipercayakan dan diberikan anak dikeluarga tersebut. Hantaran yang diberikan juga beraneka ragam, yaitu cake, telur merah, seekor ayam, spiku, gelas, handuk, kue kering. Keputusan dalam memilih hantaran yang akan digunakan juga berdasarkan pihak laki-laki sebagai kepala keluarga.

Dapat kita lihat dari hasil diatas bahwa pada pasangan orang tua dimana pihak laki-laki merupakan etnis Tionghoa, maka pihak pria akan memiliki peranan 
lebih tinggi, sehingga dalam memutuskan segala hal didasarkan pada pihak lakilaki sebagai kepala keluarga. Menurut Handoko (2014:71) dalam kehidupan berkeluarga maka pihak perempuan bisa menempatkan posisi dibawah pihak pria. Oleh karena itu dalam merayakan satu bulan bayi tradisi yang mereka gunakan adalah tradisi etnis Tionghoa.

Selain itu di dalam menentukan tradisi satu bulan bayi, juga terdapat beberapa faktor bagi pasangan orang tua etnis Tionghoa dan etnis Jawa, yaitu:

1. Pasangan orang tua lebih memilih menggunakan tradisi yang sederhana, karena tidak mau repot.

2. Adanya pasangan orang tua yang menyesuaikan dengan kemampuan ekonomi dalam memilih hantaran yang akan diberikan.

3. Mengikuti dari tradisi yang sudah dilakukan oleh teman-teman atau keluarga yang sudah merayakan satu bulan bayi terlebih dahulu.

4. Semuanya pasti memberikan hantaran kepada keluarga dan kerabat karena sebagai ungkapan syukur kepada Tuhan telah mengkaruniakan anak dalam kehidupan mereka, selain itu juga sebagai rasa terima kasih kepada orang yang sudah datang melihat anak mereka.

\section{KESIMPULAN}

Dari penelitian yang dilakukan oleh penulis kepada sepuluh pasang orang tua terhadap tradisi satu bulan bayi pada pasangan campuran etnis Tionghoa dan etnis Jawa di Surabaya, maka dapat dilihat bahwa tradisi dalam pelaksanaan perayaan satu bulan bayi ini dilaksanakan dengan cara yang sederhana. Tidak semua tradisi dilakukan baik dari etnis Tionghoa atau etnis Jawa. Tradisi yang masih banyak dilakukan yaitu tradisi memotong rambut bayi hingga gundul. Mereka mempercayai makna dari memotong rambut yaitu agar bayi lebih bersih dan mempunyai kehidupan yang lebih baik. Selain melakukan tradisi, adapun hantaran yang digunakan untuk diberikan kepada keluarga dan relasi juga beraneka ragam dan lebih sederhana. Sebagian besar jenis hantaran yang dipilih yaitu satu kotak berisi satu ekor ayam yang mempunyai makna yaitu hidup yang lebih senang dan hubungan keluarga yang erat; telur merah yang mempunyai makna yaitu kebahagian menyertai kehidupan keluarga yang bersangkutan; cake yang mempunyai makna yaitu umur panjang, kehidupan keluarga yang sukses dan banyak rejeki; gelas, handuk, dan makanan ringan yang mengikuti perkembangan zaman. Dalam menentukan tradisi apa yang akan digunakan, semua berdasarkan hasil diskusi antara suami dan istri. Selain itu terdapat beberapa faktor yang digunakan dalam merayakan satu bulan bayi.

Penulis sadar bahwa tugas akhir ini masih merupakan sebuah penelitian yang kurang mendalam dan sebagai awal dari penelitian selanjutnya. Oleh karena itu penulis berharap adanya penelitian lebih lanjut dan lebih mendalam mengenai tradisi satu bulan bayi pada pasangan campuran orang tua etnis Tionghoa dan etnis Jawa, misalnya lebih banyak narasumber dan membahas aspek yang lebih mendalam. Dengan demikian topik tugas akhir ini lebih berkembang dan dikenal oleh masyarakat luas serta memberikan manfaat kepada banyak orang agar mengetahui lebih dalam tentang tradisi satu bulan bayi. 


\section{DAFTAR PUSTAKA}

Aswiyati, I. (2015). Makna dan Jalannya Upacara "Puputan" dan”Selapanan" Dalam Adat Upacara Tradisional Kelahiran Bayi Bagi Masyarakat Jawa. Jurnal Holistik.

Bustanuddin, A. (2007). Agama Dalam Kehidupan Manusia. Jakarta: Raja Grafindo Persada.

Ekowati, V.I. (2008). Tata Cara Dan Upacara Seputar Daur Hidup Masyarakat Jawa Dalam Serat Tatacara. Jurnal Tata Cara, 12-13.

Koentjaraningrat. (2005). Ilmu Antropologi Dan Masalah Akulturasi. Medan Ilmu Pengetahuan: Rineka Cipta.

Koentjaningrat. (1987). Sejarah Teori Antropologi I. Jakarta: UI Press.

Koentjaraningrat. (2009). Ilmu Antropologi. Jakarta: PT Rineka Cipta.

Siagian, Rotua Yati. (2015). Struktur dan Makna Upacara “Manyue” Pada Suku Hokkian di Kota Medan. Universitas Sumatera Utara.

Ulumiyah, S. (2010). Kelahiran Bayi Adat Jawa. Jurnal Digilib UIN Sunan Ampel Surabaya.

Winangun. (1990). Masyarakat Bebas Struktur. Kanisius: Yogyakarta.

Yeo, Teresa Rebecca. (2013). Chinese Birth Ritual. National Library Singapore. 